\title{
AS CARACTERÍSTICAS DO OUVINTE DE RÁDIO NO BRASIL NA PERSPECTIVA DAS PESQUISAS RADIOFÔNICAS
}

\author{
THE CHARACTERISTICS OF THE RADIO LISTENER IN BRAZIL \\ FROM THE PERSPECTIVE OF RADIO RESEARCH
}

\author{
Bruno Anderson Ferreira BALACÓ ${ }^{1}$ \\ Edgard PATRÍCIO \\ Universidade Federal do Ceará | Brasil
}

\begin{abstract}
Resumo
Este artigo tem como objetivo identificar as características do ouvinte de rádio, no momento em que o veículo tem recém completado 100 anos de atuação no Brasil. Utilizamos como parâmetro uma revisão de literatura histórica sobre as pesquisas acadêmicas que versam sobre o papel da audiência radiofônica no País, nas quais foram esboçados conceitos como os de ouvinte internauta (LOPEZ, 2010), ouvinte fiel (PRATA, 2002) e ouvinte expandido (FERRAZ, 2019). Em formato de estado da arte, o levantamento mapeou um total de 25 tipologias de ouvintes. A partir dessa coleta de dados, sistematizamos, com base nas técnicas de Análise de Conteúdo (BARDIN, 2004), marcadores que sintetizam cada um desses perfis. Chegamos a 17 traços característicos, que compõem o resultado final desta pesquisa.

Palavras-chave

rádio; radiojornalismo; ouvinte; audiência; pesquisas radiofônicas.

\section{Abstract}

This paper aims to identify the characteristics of the radio listener, at a time when the vehicle has just completed 100 years of operation in Brazil. We used as a parameter a review of historical literature on academic researches that deal with the role of the radio audience in the country, where concepts such as internet user listener (LOPEZ, 2010), faithful listener (PRATA, 2002) and expanded listener (FERRAZ, 2019). In a state of the art format, the survey mapped a total of 25 types of listeners. Based on this data collection, we systematized, based on Content Analysis techniques (BARDIN, 2004), markers that synthesize each of these profiles. We reached 17 characteristic features that make up the final result of this research. Keywords

radio; radio journalism; listener; audience; radio research.
\end{abstract}

\section{RECEBIDO EM 30 DE MARÇO DE 2020}

ACEITO EM 06 DE MAIO DE 2020

1 JORNALISTA. Mestrando em Comunicação no Programa de Pós-Graduação em Comunicação da Universidade Federal do Ceará (PPGCOM-UFC) e especialista em Comunicação e Marketing em Mídias Digitais pela Estácio. Membro do Grupo de Pesquisa Práxisjor - Práxis no Jornalismo (UFC). Contato: brunoandersonfb@gmail.com.

2 JORNALISTA. Doutor em Educação pela Universidade Federal do Ceará (UFC), mestre em Educação pela UFC. É professor adjunto do curso de jornalismo da UFC, além de professor e coordenador do programa de pós-graduação em Comunicação da mesma instituição. Coordenador do Grupo de Pesquisa Práxisjor (UFC). Contato: edgard@ufc.br.

João Pessoa - Brasil |ANO 7 VOL.7 N.1|JAN./JUN. 2020| p. 301-321 


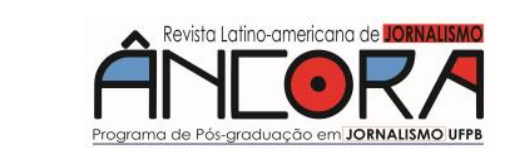

Bruno BALACó - Edgard PATRÍCIO

\section{Introdução}

sboçar o perfil do ouvinte de rádio dos dias de hoje parece uma missão
complexa, que exige um trabalho de bastante profundidade a quem
se propõe fazer esse tipo de estudo. Em meio a tantas questões a serem decifradas sobre a audiência radiofônica, um ponto surge como consenso nos estudos acadêmicos: a ideia de que o ouvinte de rádio da atualidade é peça-chave e protagonista no contexto comunicacional das emissoras, exercendo diferentes funções. Diante dos avanços tecnológicos, que abriram espaço para o surgimento de novos canais de participação, o ouvinte opina sobre os assuntos que estão sendo comentados durante a programação, envia perguntas para os apresentadores e comentaristas, sugere pautas, reclama de algo ligado ao seu cotidiano, questiona figuras públicas, desabafa sobre seus problemas, debate sobre política, economia e comenta as últimas notícias de seu time de futebol.

É com o objetivo de indicar as características do ouvinte de rádio brasileiro que propomos essa pesquisa, utilizando como referência uma revisão de literatura de perspectiva histórica, sobre os estudos radiofônicos que se debruçaram sobre o papel do ouvinte no rádio brasileiro. Diante disso, realizamos um levantamento - em formato de estado da arte - utilizando diferentes bases, como o portal de periódicos da Capes, a Biblioteca Digital Brasileira de Teses e Dissertações (BDTD) e os repositórios dos Grupos de Trabalho (GTs) dos congressos da Intercom, Compós, Alcar e SBPJor, utilizando as chaves de busca "ouvinte" e "rádio", tendo como delimitação temporal publicações das últimas duas décadas, de 2000 a 2019, compreendendo a fase contemporânea do rádio brasileiro, que se situa, segundo Zuculoto (2008), do início do século XXI aos dias atuais.

A partir dessa consulta, mapeamos 25 diferentes tipologias de ouvintes, entre conceitos bem explorados nas produções acadêmicas, como os de ouvinte internauta (LOPEZ, 2010) e ouvinte fiel (PRATA, 2002), além de termos 
recentemente esboçados, como o de ouvinte expandido (FERRAZ, 2019). Fazendo uso de técnicas de Análise de Conteúdo (BARDIN, 2004), sistematizamos em um quadro cada um desses perfis, bem como os autores que trabalharam esses termos, apontado marcadores que nos oferecerão um conjunto de características do ouvinte de rádio no País.

\section{O ouvinte radiofônico}

A noção que se tem da palavra 'ouvinte' está associada à de escuta, de recepção, em referência a qualquer indivíduo humano na situação específica em que participa de um processo comunicativo. Levado para o âmbito radiofônico, o conceito de ouvinte está ligado a aquele indivíduo que é um "seguidor da emissora, que acompanha parte ou toda a programação" (CUNHA, 2010). Pode também ser definido como "pessoa que ouve rádio" ou "pessoa ou grupo de pessoas (público) habitualmente atingidas por determinada emissora ou programa de rádio" (RABAÇA; BARBOSA, 2001).

Mais do que simplesmente escutar, o ouvinte tem um papel histórico de interação, participando da programação sonora desde as primeiras transmissões radiofônicas, que no Brasil datam do dia seis de abril de 1919, quando a Rádio Clube de Pernambuco foi ao ar pela primeira vez, em Recife. Desde então, a relação entre o rádio e sua audiência se estabeleceu por diferentes formas e canais. Nas primeiras décadas, a escuta se dava apenas através da operação de emissoras de rádio AM (Amplitude Modulada), nas modulações de ondas curtas, médias e tropicais. A partir da década de 1960, começam a surgir no Brasil as emissoras que operam em FM (Frequência Modulada), atuando como rádios comerciais, educativas ou comunitárias.

Na década de 1920, que teve como marco a primeira transmissão pública de rádio (no dia sete de setembro de 1922, no Rio de Janeiro, como parte das comemorações do centenário da Independência do Brasil) e a instalação da primeira emissora regular do País (a Rádio Sociedade do Rio de Janeiro, fundada por Edgard Roquette Pinto, em 1923), os ouvintes eram 


\section{ANEORA}

Bruno BALACó - Edgard PATRÍCIO

convidados a informar, através de cartas, sobre as condições de recepção do sinal das rádios (QUADROS, 2013). Entre as décadas de 1920 e 1930, o envio de cartas para as emissoras também era utilizado como meio de participação em concursos onde os ouvintes concorriam a prêmios. Aos poucos, foram sendo introduzidas novas formas de participação da audiência na programação. Entre as décadas de 1930 e 1940, surgiram os programas de auditório, que deram a oportunidade de o ouvinte assistir presencialmente as transmissões de programas musicais, além de rádio-novelas e humorísticos, em um cenário onde o público interagia diretamente com a emissora, de forma síncrona.

Na década de 1950, no momento em que os programas de auditório começaram a migrar do rádio para a TV (veículo que dava os primeiros passos no Brasil), o ouvinte radiofônico viu a abertura de um novo canal de participação: o telefone. Com isso, podia ligar para a emissora e até mesmo entrar ao vivo na programação. Essa estratégia foi sendo aperfeiçoada à medida que a tecnologia de telecomunicações foi se desenvolvendo até a chegada do celular, plataforma de comunicação móvel, que facilitou não só a participação da audiência, como também as coberturas externas dos repórteres, trazendo as informações com mais agilidade e praticidade direto do local dos acontecimentos, em relação à fórmula empregada até então, com o telefone sem fio utilizado nas unidades móveis de frequência modulada. Em meio a esse cenário, a internet comercial chega ao Brasil em 1995, possibilitando a participação da audiência também por meio do correio eletrônico (e-mail), chats e torpedos, num contexto que caracteriza a chamada "Fase de convergência" do rádio brasileiro:

A gradativa consolidação da telefonia celular, introduzida no país em 1990, e da internet, cujo acesso comercial é liberado aos brasileiros no ano de 1995, vai fazer com que se conforme uma nova fase histórica em termos de rádio, na qual influenciam também novos modos de acesso à informação e de relacionamento derivados destas duas tecnologias. (FERRARETTO, 2012, p. 17). 
O advento da internet também impactou de forma significativa a participação do ouvinte junto às emissoras, através do surgimento de canais de interação da audiência mais acessíveis. Dentre eles, conforme descreve Quadros (2015): os sites institucionais, através de enquetes, fóruns, seções "Fale Conosco" e de jornalismo participativo, formulários para pedidos musicais, comentários e promoções; em salas de bate-papo (chats); por correio eletrônico (e-mail); através de programas de mensagem instantânea (tais quais o MSN ou GTalk); blogs; e mais recentemente sites de redes sociais digitais (como Twitter, Facebook, Instagram e Youtube). Nestes espaços, o ouvinte tem a possibilidade de interagir com a emissora, com os profissionais e também com outros ouvintes, através de postagens em redes sociais abertas, como Facebook e Twitter. Esses novos usos, à medida que se massificam, acabam se sobrepondo às outras formas tradicionais de interatividade, como cartas, e-mails, fóruns e telefonemas, que aos poucos vão caindo em desuso.

\section{As múltiplas faces do ouvinte de rádio}

A trajetória da comunicação radiofônica mostra que o ouvinte de rádio é, antes de tudo, um sujeito inquieto. Alguém que não se contenta em apenas ouvir, informar-se e entreter-se através do veículo, mas que também quer se colocar em comunicação com o rádio, se tornar um agente da programação, um colaborador, um abastecedor, como profetizou Brecht (2005, p. 42), em seu texto 'Teoria do rádio', escrito entre 1927 e 1935, quando o veículo ainda dava os primeiros passos enquanto mídia sonora no Brasil.

A natureza inquieta e participativa do ouvinte pode ser verificada nas pesquisas dos autores que se debruçaram a estudar os múltiplos papéis da audiência ao longo da história do rádio brasileiro. Após um levantamento em produções acadêmicas nacionais, mapeamos 25 tipologias de ouvintes, que variam desde apenas rótulos atribuídos a eles até conceitos sistematizados. 


\section{ANEORA}

Bruno BALACó - Edgard PATRÍCIO

Ressalta-se que todas as categorias levadas em conta esboçam uma ideia de comportamento e características do público que acompanha essa mídia.

Um dos trabalhos mais abrangentes acerca do tema é a pesquisa de Quadros, Bespalhok, Bianchi e Kaseker (2017), que enumera oito categorias de ouvintes com validade em uma realidade comunicacional convergente, visando compreender as ações do consumidor do rádio convencional e do rádio expandido, em que as transmissões transbordam das ondas sonoras (ou hertzianas) para a TV por assinatura, sites, podcasting, dispositivos móveis e redes sociais digitais, segundo a definição de Kischinhevsky (2016).

O primeiro perfil apresentado pelas autoras é o do ouvinte aficionado, que, nos primeiros tempos de rádio no Brasil, era, acima de tudo, um curioso, um descobridor que, ao entrar em contato com o universo sonoro propiciado pelo novo meio, tornava-se um aficionado. O segundo perfil destrinchado é o de ouvinte construtor, inserido no contexto da chamada Era de Ouro do rádio brasileiro (período de profissionalização, ascensão e de maior penetração do veículo na sociedade), definido como aquele que colabora, em certa medida, na construção da programação das emissoras, que, por um lado, passa a influenciar as produções radiofônicas realizadas e, por outro, passa a operar como influenciador de outros ouvintes, ou potenciais ouvintes, de suas emissoras e programas de sua preferência.

$\mathrm{Na}$ sequência, as autoras apresentam o ouvinte consumidor, definido como aquele que participa ativamente da construção do próprio mercado de consumo cultural na Modernidade, uma vez que o veículo sempre abriu espaço para a divulgação de uma infinidade de produtos e serviços, seja em forma de publicidade, institucionalizada e permitida na radiodifusão brasileira em 1932, através de decreto que prevê que as emissoras possam ter até $10 \%$ de sua programação sob a forma de publicidade. Há casos na história do rádio brasileiro em que a própria atuação comercial deu origem ao surgimento de emissoras de rádio, como ocorreu com a Ceará Rádio Clube, inaugurada oficialmente em 1934, em Fortaleza, a partir da atuação de seu 
fundador, João Dummar, à frente da empresa que mantinha: as Casas Dummar, que revendia aparelhos radiofônicos. Por décadas, a imagem da empresa esteve associada diretamente à emissora.

O quarto e o quinto perfis também são originários da época dos programas de auditório, tão populares no rádio nas décadas de 1930 e 1940. O primeiro deles é o ouvinte fã, que tem acesso direto aos artistas que se apresentavam no rádio. Esse perfil de audiência criou a cultura dos fã-clubes e seguia os passos de seus ídolos por onde quer que fossem. O segundo perfil é o de ouvinte em cena, que inaugura um tipo de participação mais efetiva, em que o público se apresentava para jurados e outros ouvintes em busca de reconhecimento e premiação na área musical, entrando em cena e fazendo parte do espetáculo do rádio, interagindo também com vaias e aplausos durante as apresentações. Dessa forma, a audiência também era utilizada como termômetro das atrações: se a reação fosse negativa, o programa era reformulado ou retirado do ar.

No início da década de 1960, a presença do ouvinte em cena é ressignificada, no momento em que o rádio passa a adotar uma linha mais informativa, de utilidade, em que os ouvintes em cena aparecem como fontes de informação. Esse quadro se acentua na década de 1970, com a popularização do telefone como meio de participação do ouvinte, que passa a interagir com as emissoras para informar desastres, participar das seções de achados e perdidos, compartilhar receitas e se torna até fonte de pesquisa para trabalhos escolares (QUADROS et. al, 2017). É também nesse período que o rádio vive um período de reestruturação (FERRARETTO, 2001), com o início das transmissões regulares e comerciais em FM, que chegam para disputar espaço e a preferência dos ouvintes com as emissoras AM. Nesse cenário o rádio segmenta sua audiência, com cada um desses dois tipos de emissora apostando em características próprias de som e abrangência:

Seguindo a tendência verificada após o final do rádio espetáculo, as estações de amplitude modulada concentram-se no jornalismo, nas

João Pessoa - Brasil |ANO 7 VOL.7 N.1| JAN./JUN. 2020 | p. 301-321 


\section{ANEORA}

Bruno BALACÓ - Edgard PATRÍCIO

coberturas esportivas e na prestação de serviços a população. Este último aspecto, por vezes, materializa-se em programas popularescos centrados na figura de um comunicador que simula um companheirismo para o ouvinte, enquanto explora de modo sensacionalista situações do cotidiano. Nas FMs, predomina a música. Inicia um processo de divisão do público que vai se consolidar nos anos 80. (FERRARETO, 2001, p. 155)

Nesse contexto de segmentação, o rádio AM atrai um ouvinte que ganha espaço para falar de seus problemas, fazer esclarecimentos, pedidos, conselhos, queixas e orientações (MOREIRA, 2000). Ainda dentro do espectro do rádio de amplitude modulada, cabe salientar a importância do ouvinte de emissoras que operam em Ondas Curtas, que são capazes de atingir longas distâncias de propagação. Nas primeiras décadas de rádio no Brasil, muitos ouvintes utilizavam essa faixa para ouvir emissoras internacionais, captando o sinal de emissoras da Europa, por exemplo. Aos poucos, o modelo foi caindo em desuso, mas atualmente segue sendo importante no Brasil, sobretudo na região amazônica, por ser um dos poucos meios eficientes para levar informação a lugares distantes e nem sempre acessíveis pelas emissoras tradicionais.

Já o perfil dos ouvintes de emissoras FM busca cativar um público jovem e que faz uso de um estilo mais descontraído, focado em música e humor. A participação do ouvinte "manifesta-se principalmente através do telefone, fazendo seus pedidos musicais e enviando recados através da figura dos comunicadores". (QUADROS, 2013). Esse protagonismo que o ouvinte começa a ter, quando entra em cena e se torna uma fonte da programação, se consolida de vez a partir dos anos 1990, numa década marcada pela entrada do rádio na internet. É nesse contexto que surge o ouvinte-internauta. Essa tipologia é uma das oito citadas no artigo de Quadros et al. (2017) e foi sistematizada por Lopez (2010). Ao falar de um ouvinte que passa a explorar os recursos de interatividade da web, como e-mail, blog e sites de redes sociais (como Facebook e Twitter), a autora define esse perfil como sendo aquele que é "produtor de conteúdo, que gosta de participar das decisões sobre a programação da emissora", que "consome a informação em áudio enquanto 
navega, enquanto lê, enquanto circula pelas redes sociais", que "busca outras fontes de informação, cruza, contesta, discute, corrige, atualiza, conversa com o jornalista que está no ar". (LOPEZ, 2010, p. 141).

Também inserido nesse contexto de ampliação dos canais de interação através das plataformas digitais, Quadros et al. (2017) apresentam o sétimo perfil: o ouvinte participativo, identificado como aquele que passa a ganhar cada vez mais vez e voz no rádio, participando de informações e dando sugestões de pauta, repassando informações do trânsito e dos problemas da cidade. O oitavo e último perfil apresentado pelas autoras é de ouvinte convergente, que destaca o papel do ouvinte na Era da Convergência, definido como sendo aquele que participa da programação radiofônica por diferentes plataformas, como sites de redes sociais, blogs, SMS, e-mail, mensagens de áudio, etc.

A exemplo de Quadros et. al (2017), outras duas pesquisas trabalham com distintas categorias de ouvintes. A primeira delas é a de Moreira (2016), que descreve quatro tipologias, apresentando os perfis de ouvinte pauteiro, entrevistado, comentarista e repórter, formulados a partir de seu trabalho de observação etnográfica da programação de emissoras all news no dia/do rádio brasileiro, reconfigurado pelas redes sociais digitais. O ouvinte pauteiro é descrito como aquele que atua nos bastidores, compartilhando suas experiências com a emissora e sugerindo pautas para o jornalismo, em temáticas que o atingem diretamente. É também aquele que exerce um papel de cidadão, oferecendo às emissoras o compartilhamento off-line de experiências cotidianas que movem o radiojornalismo.

O ouvinte entrevistado é aquele que se aproxima da função de fonte jornalística, atuando, geralmente, em enquetes ou, ainda, como testemunha de acontecimentos. Um dos formatos mais conhecidos deste tipo de participação é o 'povo fala', modalidade utilizada por emissoras de rádio para garantir uma suposta pluralidade de vozes ao abordar assuntos em voga. Ao 


\section{ANEORA}

Bruno BALACó - Edgard PATRÍCIO

falar do ouvinte repórter, a autora contextualiza que essa tipologia supre algumas necessidades mais urgentes dos jornalistas de rádio, constantemente confrontados com a lógica do tempo ao apurar e veicular notícias sobre acontecimentos de última hora. Esse perfil é mencionado em outros trabalhos acadêmicos, como nos de Klöckner (2000), Danelli; Orlando (2015) e Jacomino; Kaseker (2017). Na dissertação de Monte (2019) há um esforço de sistematização do conceito de ouvinte repórter, descrito como aquele que colabora com a construção do conteúdo do radiojornalismo, conhece a programação, sugere pautas, faz críticas às reportagens e entrevistas (sejam elas construtivas ou não), dá opinião, informa sobre o trânsito, ajudando assim a construir o conteúdo jornalístico da rádio, fazendo uso de diversas ferramentas tecnológicas de interação.

O ouvinte comentarista, segundo Moreira (2016), é aquele que é sempre estimulado a participar de programas nos quais a opinião do público é uma das atrações, assemelhando-se, em certos casos, a um especialista. Sua participação é contemplada, sobretudo, como uma mensagem de voz gravada por meio de aplicativos bem como mensagens de texto via celular, comentários nos perfis de redes sociais online, entre outros.

A outra pesquisa que desenvolve mais de uma categoria de ouvintes é a dissertação de Maia (2017), que trabalha com três tipologias, que retratam períodos distintos de participação do ouvinte, situados na era de convergência dos meios no contexto da CBN de Curitiba, emissora que serviu como objeto de sua pesquisa. O primeiro perfil apresentado é o do ouvinte audiência, classificado como aquele que entra em contato com a emissora, principalmente por telefone, para enviar críticas, recados e algumas vezes sugestões. De acordo com a autora, esse ouvinte se comporta de forma crítica, mas tem pouca participação nas decisões ou recortes realizados pela emissora. 0 segundo perfil é o do ouvinte ativo, aquele que, facilitado em grande parte pela efetivação das redes sociais na emissora, passa a ter um papel mais ativo, enviando textos, imagens, vídeos e sons. Por fim, a autora descreve o ouvinte 
produtor, como sendo aquele que envia informações, fotos e vídeos sobre diversos fatos, principalmente sobre os relacionados ao trânsito.

Além do conceito de ouvinte repórter, outro termo trabalhado por mais de um autor nas pesquisas radiofônicas no Brasil é o de ouvinte torcedor, que aparece mencionado nos trabalhos de Guerra (2000), Silva (2010), Sousa (2013) e Farina (2018), destacado como o perfil daquele ouvinte que, nos programas esportivos e transmissões de jogos de futebol, não só ouve, mas também participa e é um interlocutor que desempenha um papel social na programação, atuando em várias frentes, seja no estádio, por telefone ou pela internet. Entende-se que a noção atribuída a esse perfil pode ser replicada ao se referir a outros personagens característicos da programação radiofônica, tais como o ouvinte taxista, sertanejo ou religioso, que aparecem citados em pesquisas acadêmicas sobre a audiência radiofônica, porém não são termos desenvolvidos de forma a descrevê-los através de conceitos ou características.

Há, contudo, em outras pesquisas radiofônicas, denominações que expressam termos clássicos da audiência no rádio que são trabalhadas como conceito. Caso da noção de ouvinte fiel, definido por Prata (2002) como sendo aquele que é um seguidor da emissora, que acompanha parte ou toda a programação, que sabe os nomes dos comunicadores, que conhece os horários dos programas, que participa com sugestões e até críticas e sente-se, de alguma forma, parte da vida da rádio. Além disso, pode ser identificado como aquele que não ouve qualquer outra emissora que não seja aquela da sua preferência absoluta. Faz ainda propaganda da rádio e induz outras pessoas a também fazerem parte do público cativo.

Outro perfil dessa natureza é o ouvinte web, descrito por Barbeiro; Lima (2001) como sendo aquele que é exigente e não se contenta em saber o que acontece. Ele quer também saber como, por que, quais os fatos geradores e como isso vai alterar a sua vida no dia a dia e sua atuação como cidadão de 


\section{ANEORA}

Bruno BALACó - Edgard PATRÍCIO

sua comunidade, país, continente e planeta. Esse perfil de consciência crítica também é uma marca registrada em outros dois perfis. Um deles é o de ouvinte cidadão, apresentado por Klöckner (2000) como aquele que discute questões mais amplas do que as que mídia lhe propõe, que é politizado, que está por dentro dos assuntos, não aceita qualquer opinião e nem os pacotes prontos apresentados pela mídia, além de propor novos temas e novas discussões. O outro é o de ouvinte militante, caracterizado, na definição de Araújo (2017), pela interferência constante nas emissoras, falando diariamente em vários programas. É como uma espécie de cronista do cotidiano, repórter informal, comentarista sem contrato de trabalho, analista não institucionalizado na hierarquia das emissoras.

Amparado no conceito de rádio expandido (Kischinhevsky, 2016), o levantamento mostrou ainda outros cinco perfis: o ouvinte enunciador, o ouvinte espectador, o ouvinte comunicador, o ouvinte fonte e o ouvinte expandido. O ouvinte enunciador é definido por Quadros; Amaral (2016) como um receptor de rádio que busca estabelecer uma relação com a emissora, utilizando-se de ferramentas interativas para enviar informações, opiniões, perguntas, correções ou críticas, e que tem sua voz, ainda que de forma indireta, inserida na narrativa. Já o ouvinte espectador, conforme a descrição de Souza; Amorim (2018) traduz aquele que é idealizado a partir de um conceito de que a audiência é diretamente atingida pela transmissão ao vivo do Facebook $e$, diferente do ouvinte tradicional de rádio, recebe as informações também através de imagens. A noção de ouvinte comunicador, formulada por Carvalho (2018), se refere a aqueles que combinam o uso de telefones celulares e das redes sociais para a promoção do protagonismo local, ao transmitirem textos, áudios e vídeos sem depender de experiências coletivas de gestão e programação de uma emissora. Nesse contexto, o ouvinte é também um usuário, que comenta, curte e compartilha utilizando as funcionalidades dos sites de redes sociais. 
Também antenado ao conteúdo radiofônico e a repercussão imediata nas redes sociais digitais está a noção de ouvinte fonte, definido por Quadros (2018) como sendo aquele que é proativo, que busca participar e intervir quase sempre que simultaneamente na narrativa que consome. Além disso, atua por iniciativa própria ou em resposta a convites à interação destinados a uma audiência massiva e anônima. A autora acrescenta que a contribuição desse perfil de ouvinte serve, muitas vezes, como alerta para uma nova pauta. Atento, atua ainda na correção imediata à informação errônea levada ao ar.

Dialogando com a própria noção de rádio expandido, surge o conceito de ouvinte expandido, definido por Ferraz (2019) como sendo aquele que, a cada interação, sente-se parte do sistema de construção dos conteúdos transmitidos pelo rádio ou por um podcast. opina, informa, faz perguntas, estabelece pautas, transforma-se em fonte da informação, põe no ar sua voz - ainda que controlada pelo emissor em seu antigo papel - e transforma sua atitude social a partir da interação com redes de ouvintes, constituindo uma comunidade despida de territorialidade pela característica digital da comunicação.

\section{Análise do perfil do ouvinte de rádio no Brasil}

A partir da apresentação das 25 tipologias de ouvintes mapeados nas pesquisas radiofônicas brasileiras, organizamos um quadro que sistematiza cada um desses perfis. A partir da definição dada pelos autores em suas pesquisas, apontamos marcadores que identificam o comportamento de cada um dos termos. A soma dos traços definidores de cada tipologia constituirá a ideia do que seriam as características presentes no ouvinte brasileiro, sob a perspectiva das pesquisas radiofônicas realizadas no País. A construção do quadro a seguir é baseada nos conceitos apresentados anteriormente neste trabalho, através de pesquisadores que se debruçaram em estudos sobre o ouvinte radiofônico. Nessa etapa, recorremos às técnicas da Análise de Conteúdo, metodologia descrita por Bardin (2004) como sendo a que faz uso 


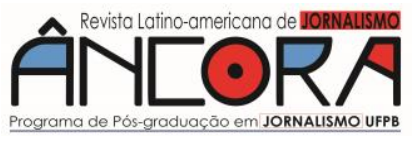

Bruno BALACÓ - Edgard PATRÍCIO

de um "conjunto de técnicas de análise das comunicações visando obter por procedimentos sistemáticos e objetivos de descrição do conteúdo das mensagens dos indicadores (quantitativos ou não)". A conferir:

Quadro 1: Perfis de ouvintes trabalhados em pesquisas radiofônicas:

\begin{tabular}{|c|c|c|c|}
\hline $\begin{array}{l}\text { TIPO DE } \\
\text { OUVINTE }\end{array}$ & DEFINIÇÃO & $\begin{array}{l}\text { AUTORES QUE } \\
\text { TRABALHAM O } \\
\text { TERMO }\end{array}$ & $\begin{array}{l}\text { MARCADORES } \\
\text { CARACTERÍSTIC } \\
\text { OS }\end{array}$ \\
\hline $\begin{array}{l}\text { Ouvinte } \\
\text { aficionado }\end{array}$ & $\begin{array}{l}\text { Ouvinte curioso, um descobridor, que, } \\
\text { ao entrar em contato com o universo } \\
\text { sonoro proporcionado pelo rádio, se } \\
\text { torna um aficionado. }\end{array}$ & $\begin{array}{c}\text { - Quadros; } \\
\text { Bespalhok, } \\
\text { Bianchi; Kaseker } \\
\text { (2017) }\end{array}$ & $\begin{array}{l}\text { - Entusiasta com o } \\
\text { veículo rádio }\end{array}$ \\
\hline $\begin{array}{l}\text { Ouvinte } \\
\text { construtor }\end{array}$ & $\begin{array}{l}\text { Ouvinte que colabora, em certa } \\
\text { medida, na construção da } \\
\text { programação das emissoras, que passa } \\
\text { a influenciar as produções radiofônicas } \\
\text { realizadas, a operar como } \\
\text { influenciadores de outros ouvintes, ou } \\
\text { potenciais ouvintes, de suas emissoras } \\
\text { e programas de preferência. }\end{array}$ & $\begin{array}{c}\text { - Quadros; } \\
\text { Bespalhok, } \\
\text { Bianchi; Kaseker } \\
\text { (2017) }\end{array}$ & $\begin{array}{l}\text { - Colabora com a } \\
\text { construção de } \\
\text { conteúdos }\end{array}$ \\
\hline $\begin{array}{l}\text { Ouvinte } \\
\text { consumidor }\end{array}$ & $\begin{array}{l}\text { Ouvinte que participa ativamente da } \\
\text { construção do próprio mercado de } \\
\text { consumo cultural da modernidade. }\end{array}$ & $\begin{array}{c}\text { - Quadros; } \\
\text { Bespalhok, } \\
\text { Bianchi; Kaseker } \\
\text { (2017) }\end{array}$ & $\begin{array}{l}\text { - Participa da } \\
\text { construção do } \\
\text { mercado de } \\
\text { consumo cultural a } \\
\text { partir do rádio }\end{array}$ \\
\hline Ouvinte fã & $\begin{array}{l}\text { Ouvintes que têm acesso direto aos } \\
\text { seus ídolos e criam a cultura de fãs- } \\
\text { clubes de suas referências no rádio. }\end{array}$ & $\begin{array}{c}\text { - Quadros; } \\
\text { Bespalhok, } \\
\text { Bianchi; Kaseker } \\
\text { (2017) }\end{array}$ & $\begin{array}{l}\text { - Cultua os artistas } \\
\text { que se apresentam } \\
\text { no rádio }\end{array}$ \\
\hline $\begin{array}{l}\text { Ouvinte em } \\
\text { cena }\end{array}$ & $\begin{array}{l}\text { Ouvinte que participa efetivamente dos } \\
\text { programas, entrando em cena e } \\
\text { fazendo parte do espetáculo do rádio. } \\
\text { Colabora como fonte na programação. }\end{array}$ & $\begin{array}{c}\text { - Quadros; } \\
\text { Bespalhok, } \\
\text { Bianchi; Kaseker } \\
\text { (2017) }\end{array}$ & $\begin{array}{l}\text { - Participação ativa } \\
\text { como parte do } \\
\text { espetáculo do } \\
\text { rádio } \\
\text { - Atua como fonte } \\
\text { jornalística }\end{array}$ \\
\hline $\begin{array}{l}\text { Ouvinte } \\
\text { internauta }\end{array}$ & $\begin{array}{l}\text { É um produtor de conteúdo, que gosta } \\
\text { de participar das decisões sobre a } \\
\text { programação da emissora. Consome a } \\
\text { informação em áudio enquanto } \\
\text { navega, enquanto lê, enquanto circula } \\
\text { pelas redes sociais. Busca outras } \\
\text { fontes de informação, cruza, contesta, } \\
\text { discute, corrige, atualiza, conversa com } \\
\text { o jornalista que está no ar. }\end{array}$ & - Lopez (2010) & $\begin{array}{l}\text { - Colabora com a } \\
\text { construção de } \\
\text { conteúdos } \\
\text {-Corrige } \\
\text { informações } \\
\text { - Contesta } \\
\text { - Faz críticas }\end{array}$ \\
\hline $\begin{array}{c}\text { Ouvinte } \\
\text { participativo }\end{array}$ & $\begin{array}{l}\text { É o ouvinte que participa com } \\
\text { informações e dando sugestões de } \\
\text { pauta, repassando informações do } \\
\text { trânsito e dos problemas da cidade. }\end{array}$ & $\begin{array}{c}\text { - Quadros; } \\
\text { Bespalhok, } \\
\text { Bianchi; Kaseker } \\
\text { (2017) }\end{array}$ & $\begin{array}{c}\text { - Sugere pautas } \\
\text { - Atua como fonte } \\
\text { jornalística - } \\
\text { Denuncia } \\
\text { problemas. }\end{array}$ \\
\hline
\end{tabular}




\begin{tabular}{|c|c|c|c|}
\hline $\begin{array}{l}\text { Ouvinte } \\
\text { Convergente }\end{array}$ & $\begin{array}{l}\text { É o ouvinte que participa por } \\
\text { diferentes plataformas, como sites de } \\
\text { redes sociais, blogs, SMS, e-mail, } \\
\text { mensagens de áudio, etc. }\end{array}$ & $\begin{array}{l}\text { - Quadros, } \\
\text { Bespalhok, } \\
\text { Bianchi e } \\
\text { Kaseker (2017) }\end{array}$ & $\begin{array}{l}\text { - Colabora com a } \\
\text { construção de } \\
\text { conteúdos }\end{array}$ \\
\hline $\begin{array}{l}\text { Ouvinte } \\
\text { repórter }\end{array}$ & $\begin{array}{c}\text { Aquele que colabora com a construção } \\
\text { do conteúdo, que conhece a } \\
\text { programação, sugere pautas, faz } \\
\text { críticas às reportagens e entrevistas, } \\
\text { dá opinião, informa sobre o trânsito, } \\
\text { ajuda a construir o conteúdo } \\
\text { jornalístico da emissora, fazendo uso } \\
\text { de diversas ferramentas tecnológicas } \\
\text { de interação. }\end{array}$ & $\begin{array}{l}\text { - Monte (2019) } \\
\text { - Danelli; } \\
\text { Orlando (2015) } \\
\text { - Klöckner (2000) } \\
\text { - Jacomino; } \\
\text { Kakeser (2017) } \\
\text { - Pessoa (2016) }\end{array}$ & $\begin{array}{l}\text { - Colabora com a } \\
\text { construção do } \\
\text { conteúdo } \\
\text { - Sugere pautas } \\
\text { - Faz críticas } \\
\text { - Emite opiniões }\end{array}$ \\
\hline $\begin{array}{l}\text { Ouvinte } \\
\text { enunciador }\end{array}$ & $\begin{array}{c}\text { Receptor de rádio que busca } \\
\text { estabelecer uma relação com a } \\
\text { emissora, utilizando-se de ferramentas } \\
\text { interativas para enviar informações, } \\
\text { opiniões, perguntas, correções ou } \\
\text { críticas, e que tem sua voz, ainda que } \\
\text { de forma indireta, inserida na } \\
\text { narrativa. }\end{array}$ & $\begin{array}{c}\text { - Quadros; } \\
\text { Amaral (2016). }\end{array}$ & $\begin{array}{l}\text { - Colabora com a } \\
\text { construção dos } \\
\text { conteúdos } \\
\text { - Emite opiniões } \\
\text {-Corrige } \\
\text { informações } \\
\text { - Faz críticas }\end{array}$ \\
\hline $\begin{array}{c}\text { Ouvinte } \\
\text { comentarista }\end{array}$ & $\begin{array}{l}\text { É sempre estimulado a participar de } \\
\text { programas nos quais a opinião do } \\
\text { público é uma das atrações } \\
\text { assemelhando-se, em certos casos, a } \\
\text { um especialista. Sua participação é } \\
\text { contemplada, sobretudo, como uma } \\
\text { mensagem de voz gravada por meio } \\
\text { de aplicativos bem como mensagens } \\
\text { de texto via celular, comentários nos } \\
\text { perfis de redes sociais online, entre } \\
\text { outros. }\end{array}$ & - Pessoa (2016) & - Emite opiniões \\
\hline $\begin{array}{l}\text { Ouvinte } \\
\text { cidadão }\end{array}$ & $\begin{array}{l}\text { Discute questões mais amplas do que } \\
\text { as que mídia Ihe propõe. E politizado, } \\
\text { está por dentro dos assuntos, não } \\
\text { aceita qualquer opinião e nem os } \\
\text { pacotes prontos apresentados pela } \\
\text { mídia. Propõe novos temas e novas } \\
\text { discussões. }\end{array}$ & - Klöckner (2000) & $\begin{array}{l}\text { - Colabora com a } \\
\text { construção dos } \\
\text { conteúdos }\end{array}$ \\
\hline $\begin{array}{l}\text { Ouvinte } \\
\text { pauteiro }\end{array}$ & $\begin{array}{l}\text { Atua nos bastidores, compartilhando } \\
\text { suas experiências com a emissora e } \\
\text { sugere pautas para o jornalismo, em } \\
\text { temáticas que o atingem diretamente. } \\
\text { É também aquele que exerce um papel } \\
\text { de cidadão, oferecendo às emissoras o } \\
\text { compartilhamento off-line de } \\
\text { experiências cotidianas que movem o } \\
\text { radiojornalismo. }\end{array}$ & - Pessoa (2016) & \\
\hline $\begin{array}{c}\text { Ouvinte } \\
\text { entrevistado }\end{array}$ & $\begin{array}{l}\text { Aproxima-se da função de fonte } \\
\text { jornalística, atuando, geralmente, em } \\
\text { enquetes ou, ainda, como testemunha }\end{array}$ & - Pessoa (2016) & $\begin{array}{l}\text { - Atua como fonte } \\
\text { jornalística - É }\end{array}$ \\
\hline
\end{tabular}




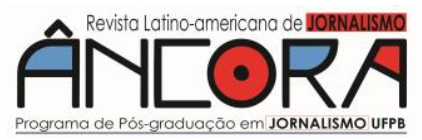

Bruno BALACÓ - Edgard PATRÍCIO

\begin{tabular}{|c|c|c|c|}
\hline & $\begin{array}{l}\text { de acontecimentos. Um dos formatos } \\
\text { mais conhecidos deste tipo de } \\
\text { participação é o 'povo fala'. }\end{array}$ & & $\begin{array}{l}\text { testemunha de } \\
\text { acontecimentos }\end{array}$ \\
\hline $\begin{array}{l}\text { Ouvinte } \\
\text { espectador }\end{array}$ & $\begin{array}{l}\text { Idealizado a partir de um conceito de } \\
\text { que a audiência diretamente atingida } \\
\text { pela transmissão ao vivo do Facebook } \\
\text { não se enquadra como ouvinte } \\
\text { tradicional de rádio, porque recebe as } \\
\text { informações também através de } \\
\text { imagens. Porém também não se } \\
\text { enquadra como espectador tradicional, } \\
\text { pois esse formato não pretende se } \\
\text { transformar em televisão e muito } \\
\text { menos informar exclusivamente por } \\
\text { imagens. }\end{array}$ & $\begin{array}{l}\text { - Souza; Amorim } \\
\text { (2018). }\end{array}$ & $\begin{array}{l}\text { - Assiste a } \\
\text { transmissões de } \\
\text { programa de rádio } \\
\text { pelas redes sociais }\end{array}$ \\
\hline $\begin{array}{l}\text { Ouvinte } \\
\text { militante }\end{array}$ & $\begin{array}{l}\text { Caracteriza-se pela interferência } \\
\text { constante nas emissoras, falando } \\
\text { diariamente em vários programas. São } \\
\text { cronistas do cotidiano, repórteres } \\
\text { informais, comentaristas sem contrato } \\
\text { de trabalho, analistas não } \\
\text { institucionalizados na hierarquia das } \\
\text { emissoras. }\end{array}$ & - Araújo (2017) & $\begin{array}{l}\text { - Emite opinião } \\
\text { - Atua como fonte } \\
\text { jornalística } \\
\text { - Colabora com a } \\
\text { construção de } \\
\text { conteúdos }\end{array}$ \\
\hline $\begin{array}{l}\text { Ouvinte } \\
\text { comunicador }\end{array}$ & $\begin{array}{l}\text { Combinam o uso de telefones celulares } \\
\text { e das redes sociais para a promoção } \\
\text { do protagonismo local, ao transmitirem } \\
\text { textos, áudios e vídeos sem depender } \\
\text { de experiências coletivas de gestão e } \\
\text { programação de uma emissora. }\end{array}$ & $\begin{array}{l}\text { - Carvalho } \\
\text { (2018) }\end{array}$ & $\begin{array}{l}\text { - Colabora com a } \\
\text { construção de } \\
\text { conteúdos } \\
\text { - Sugere pautas }\end{array}$ \\
\hline Ouvinte web & $\begin{array}{c}\text { É exigente. Não basta saber o que } \\
\text { acontece, ele quer saber como, por } \\
\text { que, quais os fatos geradores e como } \\
\text { isso vai alterar a sua vida no dia a dia } \\
\text { e sua atuação como cidadão de sua } \\
\text { comunidade, país, continente e } \\
\text { planeta. }\end{array}$ & $\begin{array}{l}\text { - Barbeiro; Lima } \\
\text { (2001) }\end{array}$ & $\begin{array}{l}\text { - Contesta } \\
\text { - Faz críticas }\end{array}$ \\
\hline $\begin{array}{l}\text { Ouvinte } \\
\text { fonte }\end{array}$ & $\begin{array}{l}\text { É proativo, que busca participar e } \\
\text { intervir quase sempre que } \\
\text { simultaneamente na narrativa que } \\
\text { consome. Além disso, atua por } \\
\text { iniciativa própria ou em resposta a } \\
\text { convites à interação destinados a uma } \\
\text { audiência massiva e anônima. Serve, } \\
\text { muitas vezes, como alerta para uma } \\
\text { nova pauta. Atento, atua ainda na } \\
\text { correção imediata à informação } \\
\text { errônea levada ao ar. }\end{array}$ & - Quadros (2018) & $\begin{array}{c}\text {-Corrige } \\
\text { informações } \\
\text { - Sugere pautas } \\
\text { - Atua como fonte } \\
\text { jornalística }\end{array}$ \\
\hline Ouvinte fiel & $\begin{array}{c}\text { É um seguidor da emissora, que } \\
\text { acompanha parte ou toda a } \\
\text { programação, sabe os nomes dos } \\
\text { comunicadores, conhece os horários } \\
\text { dos programas, participa com } \\
\text { sugestões e até críticas e sente-se, de }\end{array}$ & - Prata (2002) & $\begin{array}{l}\text { - Sugere pautas } \\
\text { - Faz críticas } \\
\text { - Engaja novos } \\
\text { ouvintes para a } \\
\text { emissora }\end{array}$ \\
\hline
\end{tabular}




\begin{tabular}{|c|c|c|c|}
\hline & $\begin{array}{l}\text { alguma forma, parte da vida da rádio. } \\
\text { É também aquele que não ouve } \\
\text { qualquer outra emissora que não seja } \\
\text { aquela da sua preferência. Faz ainda } \\
\text { propaganda da rádio e induz outras } \\
\text { pessoas a também fazerem parte do } \\
\text { público cativo. }\end{array}$ & & \\
\hline $\begin{array}{l}\text { Ouvinte } \\
\text { torcedor }\end{array}$ & $\begin{array}{l}\text { Nos programas esportivos e } \\
\text { transmissões de jogos de futebol, não } \\
\text { só ouve, mas também participa e é um } \\
\text { interlocutor que desempenha um papel } \\
\text { social na programação, atuando em } \\
\text { várias frentes, seja no estádio, por } \\
\text { telefone ou pela internet. }\end{array}$ & $\begin{array}{l}\text { - Guerra (2000) } \\
\text { - Farina (2018) } \\
\text { - Sousa (2013) } \\
\text { - Silva (2010) }\end{array}$ & $\begin{array}{l}\text { - Emite opinião } \\
\text { - Colabora com a } \\
\text { construção de } \\
\text { conteúdos }\end{array}$ \\
\hline $\begin{array}{l}\text { Ouvinte } \\
\text { expandido }\end{array}$ & $\begin{array}{l}\text { Aquele que, a cada interação, sente-se } \\
\text { parte do sistema de construção dos } \\
\text { conteúdos transmitidos pelo rádio ou } \\
\text { por um podcast: opina, informa, faz } \\
\text { perguntas, estabelece pautas, } \\
\text { transforma-se em fonte da informação, } \\
\text { põe no ar sua voz - ainda que } \\
\text { controlada pelo emissor em seu antigo } \\
\text { papel - e transforma sua atitude social } \\
\text { a partir da interação com redes de } \\
\text { ouvintes, constituindo uma } \\
\text { comunidade despida de territorialidade } \\
\text { pela característica digital da } \\
\text { comunicação. }\end{array}$ & - Ferraz (2019) & $\begin{array}{l}\text { - Colabora com a } \\
\text { construção de } \\
\text { conteúdos } \\
\text { - Sugere pautas } \\
\text { - Emite opiniões } \\
\text { - Atua como fonte } \\
\text { jornalística }\end{array}$ \\
\hline $\begin{array}{c}\text { Ouvinte } \\
\text { audiência }\end{array}$ & $\begin{array}{l}\text { Entram em contato com a emissora } \\
\text { principalmente por telefone para envia } \\
\text { críticas, recados e algumas vezes } \\
\text { sugestões. Consome as informações } \\
\text { de forma crítica, mas com pouca } \\
\text { participação nas decisões ou recortes } \\
\text { realizados pela emissora. }\end{array}$ & - Maia (2017) & $\begin{array}{l}\text { - Faz críticas } \\
\text { - Sugere pautas }\end{array}$ \\
\hline Ouvinte ativo & $\begin{array}{l}\text { Facilitado em grande parte pela } \\
\text { efetivação das redes sociais na } \\
\text { emissora, passa a ter um papel mais } \\
\text { ativo, enviando textos, imagens, } \\
\text { vídeos e sons. }\end{array}$ & - Maia (2017) & $\begin{array}{l}\text { - Colabora com a } \\
\text { construção de } \\
\text { conteúdos } \\
\text { - Faz críticas }\end{array}$ \\
\hline $\begin{array}{l}\text { Ouvinte } \\
\text { produtor }\end{array}$ & $\begin{array}{l}\text { Aquele que envia informações, fotos e } \\
\text { vídeos sobre diversos fatos, } \\
\text { principalmente sobre os relacionados } \\
\text { ao trânsito. }\end{array}$ & - Maia (2017) & $\begin{array}{l}\text { - Colabora com a } \\
\text { construção de } \\
\text { conteúdos } \\
\text { - Sugere pautas }\end{array}$ \\
\hline
\end{tabular}

Fonte: elaborado pelo autor.

A análise das 25 tipologias listadas acima detectou 17 traços característicos de comportamento do ouvinte, a partir das pesquisas radiofônicas brasileiras. São eles: 1) Entusiasta com o veículo rádio, 2) Colabora com a construção de conteúdos, 3) Participa da construção do

João Pessoa - Brasil |ANO 7 VOL.7 N.1| JAN./JUN. 2020 | p. 301-321 


\section{AN[ORA}

Bruno BALACó - Edgard PATRÍCIO

mercado de consumo cultural a partir do rádio, 4) Cultua os artistas que se apresentam no rádio, 5) Participa de forma ativa como parte do espetáculo do rádio, 6) Colabora com a construção de conteúdos, 7) Corrige informações, 8) Contesta, 9) Faz críticas, 10) Sugere pautas, 11) Atua como fonte jornalística, 12) Faz denúncias, 13) Emite opiniões, 14) Compartilha experiências cotidianas, 15) É testemunha de acontecimentos, 16) Assiste a transmissões de programas de rádio pelas redes sociais e 17) Engaja novos ouvintes para a emissora.

Entre os marcadores, observaram-se duas características recorrentes nos perfis descritos nas pesquisas radiofônicas no Brasil: a do ouvinte que colabora com a construção dos conteúdos, que aparece em 12 das 25 tipologias (quase metade do total), e a do ouvinte que sugere pautas, identificado em nove tipologias. Destaque também para o indicador de ouvinte como fonte jornalística, que faz críticas e o que emite opiniões, que aparecem em quatro perfis.

A análise das 25 tipologias de ouvinte apresentadas também nos permite concluir que muitos dos perfis se entrecruzam na cronologia do rádio brasileiro e apresentam um alto grau de semelhança em suas definições. É o caso dos perfis dos ouvintes pauteiro, comunicador, repórter, enunciador e audiência, que trazem como elemento central característico: a sugestão de pauta. Observamos também o mesmo cenário nos perfis de ouvinte fonte e ouvinte entrevistado, que apresentam como essência a atuação da audiência como fonte na programação.

\section{Considerações finais}

Tendo em vista que o levantamento contempla pesquisas de âmbito acadêmico em diferentes níveis, entre periódicos, dissertações e teses desenvolvidas por muitos dos principais pesquisadores de rádio do País, num espaço de tempo de publicação considerável, de duas décadas (entre 2000 e 2019), entendemos que o resultado final, que apontou 17 marcadores, 
apresenta um recorte significativo das características do ouvinte de rádio brasileiro, que exaltam a variedade de papéis que a audiência radiofônica desempenha atualmente.

Vale ressaltar que os perfis/termos/tipos/conceitos de ouvintes apresentados são frutos de análises em diferentes objetos empíricos pelo País - sobretudo na atuação das emissoras informativas - obtendo resultados a partir de diferentes técnicas metodológicas, tais como observação sistemática, análise de conteúdo e entrevistas. Essa abrangência de métodos e objetos de estudo nos dá a segurança de que o levantamento buscou ser o mais amplo possível na missão de identificar o perfil dos ouvintes de rádio.

Ressalta-se, contudo, que este estudo não teve a pretensão de representar uma totalidade de papéis e funções que o ouvinte radiofônico tem desempenhado nas últimas duas décadas. A intenção desta pesquisa foi retratar sobre o que os pesquisadores brasileiros têm identificado quanto aos perfis e características da audiência radiofônica. Espera-se que este trabalho sirva como ponto de partida para novos levantamentos sobre o papel do ouvinte de rádio e que se possa também mapear novas características ou mesmo outros elementos que o mapeamento não conseguiu alcançar, até mesmo para reafirmar o que foi dito aqui, de que o ouvinte é um sujeito inquieto e, tal qual o rádio, está em constante processo de reinvenção.

\section{Referências}

AMORIM, Francisco; SOUZA, Patrícia. As vozes do Rádio têm rostos: 0 programa Gaúcha Hoje e os processos de produção das transmissões ao vivo no Facebook. In: VIII JPJOR, São Paulo, 2018.

ARAÚJO, Ed Wilson Ferreira. Ágora Eletrônica: Tipologia da Audiência Militante nos Programas Jornalísticos de Rádio AM, em São Luís. In: $40^{\circ}$ Congresso Brasileiro de Ciências da Comunicação (Intercom): Curitiba, 2017. BARBEIRO, Heródoto; LIMA, Paulo Rodolfo de. Manual de radiojornalismo. Rio de Janeiro: Campos, 2001.

BARDIN, Laurance. Análise de Conteúdo. Lisboa: Edições 70, 2004. BRECHT, Bertold. Teoria do rádio. In: MEDITSCH, Eduardo (Org.). Teorias do Rádio - Textos e Contextos. Florianópolis: Insular, 2005. 


\section{AN[ORA}

Bruno BALACÓ - Edgard PATRÍCIO

CUNHA, Magda. In: Enciclopédia INTERCOM de Comunicação. Sociedade Brasileira de Estudos Interdisciplinares da Comunicação, São Paulo, 2010. DANELLI, Carolina; ORLANDO, Simone. 0 uso do WhatsApp na rotina de produção de rádio BandNews Fluminense FM. In: $38^{\circ}$ Congresso Brasileiro de Ciências da Comunicação (Intercom): Rio de Janeiro, 2015. FARINA, Marcelo. Recepção de mensagens jornalísticas esportivas na Rádio Gaúcha. Dissertação (Faculdade Casper Líbero): São Paulo, 2018. FERRARETTO, Luiz Artur. Rádio: o veículo a história e a técnica. Porto Alegre: Ed. Sagra Luzzato, 2001.

FERRARETTO, Luiz Artur. Uma proposta de periodização para a história do rádio no Brasil. Revista da economia política de las tecnologias de lainformación y de lacomunicación, São Cristóvão, v. 14, n.2, p. 1-24, maio/ago. 2012.

FERRAZ, Nivaldo. Um conceito de ouvinte expandido. Rev. Rumores (USP), v. 13, p. 274-293, 2019.

GUERRA, Márcio. Você, ouvinte, é a nossa meta: a importância do rádio no imaginário do torcedor do futebol. 1.ed. Rio de Janeiro: Etc Editora, 2002. JACOMINO, Giovanni; KASEKER, Mônica. Você é o Repórter?: Uma análise sobre a participação do ouvinte na Rádio Paiquerê. In: $40^{\circ}$ Congresso Brasileiro de Ciências da Comunicação - Intercom Júnior, Curitiba, 2017.

KISCHINHEVSKY, Marcelo. Rádio e mídias sociais: Mediações e interações radiofônicas em plataformas digitais de comunicação. Rio de Janeiro: Mauad X, 2016.

KLÖCKNER, Luciano. Radiojornalismo de serviço: o rumo da AM em tempos de internet. In: XXIII Congresso Brasileiro de Ciência da Comunicação (Intercom), Manaus, 2000.

LOPEZ, Debora Cristina. Radiojornalismo hipermidiático: tendências e perspectivas do jornalismo de rádio allnews brasileiro em um contexto de convergência tecnológica. Covilhã, Portugal: LabCom, 2010.

LOPEZ, Debora; QUADROS, Mirian. O rádio e a relação com o ouvinte no cenário de convergência: uma proposta de classificação dos tipos de interatividade. Famecos, v.22, n.3, p. 164-181, 2015.

MAIA, Bárbara. 0 processo de convergência no radiojornalismo: transformações profissionais na rádio CBN-Curitiba. Dissertação (UFPR): Curitiba, 2017.

MONTE, Rachel Gomes Braga. WhatsApp e seleção de pautas: o processo de gatekeeper no programa o povo no rádio e as estratégias do ouvinterepórter para emplacar pautas na programação. Dissertação (UFC): Fortaleza, 2019.

QUADROS, Mirian; AMARAL, Márcia Franz. O ouvinte-enunciador nas narrativas radiofônicas: as disputas pelo poder de voz. Rizoma, v. 4, n. 2, p. 108-121, dez. 2016.

PESSOA, Sônia. O empoderamento sutil do ouvinte no radiojornalismo: os desafios de uma cultura além da escuta. In: XXIX Congresso Brasileiro de Ciência da Comunicação (Intercom): São Paulo, 2016. 
PRATA, Nair. A fidelidade do ouvinte de rádio. In: XXV Congresso Brasileiro de Ciência da Comunicação (Intercom): Salvador, 2002.

RABAÇA, Carlos Alberto; BARBOSA, Gustavo. Dicionário de Comunicação. São Paulo: Ática, 2001.

QUADROS, Cláudia Irene de; BESPALHOK, Flávia Lúcia Bazan; BIANCHI, Graziela Soares; KASEKER, Mônica Panis. Perfis de ouvintes:perspectivas e desafios no panorama radiofônico. Revista Matrizes. v.11, n. 1 jan./abr. São Paulo, 2017

QUADROS, Mirian Redin de. As redes sociais no jornalismo radiofônico: as estratégias interativas adotadas pelas rádios Gaúcha e CBN. Dissertação (UFSM): Santa Maria, 2013.

QUADROS, Mirian Redin de. O ouvinte no rádio: uma análise históricodescritiva da interatividade radiofônica. In: IX Encontro Nacional de História da Mídia (Alcar): Ouro Preto, 2013.

QUADROS, Mirian Redin de. O lugar do ouvinte nas narrativas radiofônicas: concessão de voz e critérios de acionamento dos ouvintesenunciadores. Tese (UFSM), Santa Maria, 2018.

SILVA, Ednelson. Narração esportiva no rádio: subjetividade e singularidade do narrador. In: ECCOM: Lorena-SP, 2010.

SOUSA, Pedro Henrique. Estratégias e vozes narrativas nas transmissões esportivas: o futebol no rádio. Dissertação (PUC-MG): Belo Horizonte, 2013.

ZUCULOTO, Valci Regina Mousquer. As grandes fases do Rádio Público brasileiro: em busca de uma periodização para pesquisas históricas deste segmento da radiofonia nacional. In: XXXI Congresso Brasileiro de Ciência da Comunicação (Intercom): Natal, 2008. 